\title{
Vineyard performance and fruit quality of some interspecific grapevine cultivars in cool climate conditions
}

\author{
Maciej Gąstol \\ Department of Pomology and Apiculture \\ University of Agriculture in Krakow \\ 29 Listopada 54, 31-425 Kraków, Poland
}

\begin{abstract}
A study of 13 grapevine cultivars was carried out in a vineyard located near Krakow (Poland) in order to identify the most suitable grapevine cultivars for cool climate regions. The vines' vigour, yield and the yield efficiency index were studied in the years 2010-2013. The grapes were analysed to determine soluble solids content (SSC), titratable acidity, total polyphenol content (TPC) as well as fruit antioxidant activity (FRAP). Moreover, organic acid concentrations (tartaric, malic, citric and ascorbic) were ascertained. Significant fluctuations in yield and quality were caused by variable climatic conditions during the vegetation period, especially before the vintage. SSC varied from $15.7^{\circ}$ Brix ('Swenson Red') to $20.8^{\circ}$ Brix ('Frontenac'). The highest sugar:acid ratio was measured for 'Regent' as well as for 'Hibernal' and 'Muskat Odesskij' among white grapes. The lowest concentration of tartaric acid was measured for 'Frontenac' $\left(1.03 \mathrm{~g} \mathrm{~L}^{-1}\right)$ as well as 'Jutrzenka' $\left(1.76 \mathrm{~g} \mathrm{~L}^{-1}\right)$. The latter cultivar tended to accumulate one of the highest amounts of malic and citric acid. The highest total polyphenol content along with outstanding antioxidant activity was measured for the following red cultivars: 'Frontenac', 'Leon Millot' and 'Marechal Foch'. The most promising cultivars were 'Seyval Blanc', 'Aurora' and 'Regent', which performed well in terms of their moderate vigour, increased fruitfulness and consistently higher yields.
\end{abstract}

Key words: Vitis sp., environmental factors, vigour, productivity, fruit composition, antioxidants

\section{INTRODUCTION}

With an annual production of over 67 million tonnes (FAO 2012), grapevine is one of the most important fruit crops. However, as the climate becomes warmer, it can be expected that significant changes in the distribution of viticulture may occur (Gustafsson and Mårtensson 2005). Presently, grapevine cultivation is also becoming more and more popular in the colder regions of Europe. Although in Poland Vitis sp. has not been of special importance, today we can observe a real renaissance of its cultivation. Over 700 ha of vineyards have been planted and new vinery production regions have appeared (EUROSTAT 2012). Although these areas are subjected to the risk of severe winter injury in some years, the grapes and wines obtained are often of outstanding quality, having a high aroma and antioxidant status (DobrowolskaIwanek et al. 2014). However, there are some more factors that may negatively affect the quality of cool climate grapes, such as low sugar content or high malic acid concentration due to frequent deviations of weather during grape maturation. Therefore, plant adaptability and the fruit quality of wine 
grape cultivars in such regions should be studied comprehensively before they are widely planted.

As interspecific hybrids of Vitis ssp. are more suitable for colder regions, especially in terms of their resistance, in many countries, including Poland, the selection and evaluation programs of these cultivars have begun (Lisek 2005, 2010). Therefore, the purpose of this study was to determine the growth, productivity and grape quality traits of the most promising cultivars best suited for cool climate wine production.

\section{MATERIAL AND METHODS}

The study was carried out in the "Garlicki Lamus" vineyard located in Garlica Murowana (near Kraków, Poland, coordinates: $19^{\circ} 56^{\prime} \mathrm{E}$ and $50^{\circ} 08^{\prime} \mathrm{N}$ ) in $2010-2013$.

\section{Plant material}

Thirteen grapevine cultivars were included in the study (Tab. 1).

Cultivars with the numbers 1-7 bear white grapes, while 8-13 bear red ones. All of the studied cultivars are interspecific hybrids, while some ('Regent', 'Rondo', 'Hibernal' and 'Sibera') are classified as inter-intraspecific hybrids belonging to Vitis vinifera L. according to systematics. Among the mentioned cultivars, 'Leon Millot', 'Marechal Foch', 'Aurora' and 'Seyval Blanc' are classified as French-American hybrids. All cultivars were grafted on $\mathrm{SO} 4$ rootstock with the exception of 'Muscat Odeski' (grafted on LE-K1 rootstock) and 'Jutrzenka' (Teleki 8B).
The experiment was arranged in a randomized complete-block design. Each cultivar was represented by four replications of five vines per block. Grapevines rows were north-south oriented with $3.5 \mathrm{~m}$ spacing between rows and 0.9 in-row, respectively (3200 vines $\left.\mathrm{ha}^{-1}\right)$. The four-yearold vines were trained as horizontal unilateral cordons. Each plant was pruned to one nine-node cane. Weeds between plants were controlled by application of glyphosate (Roundup, Monsanto) in mid-June every year. Vineyard management was carried out according to the recommendations for commercial vineyards in Poland (Myśliwiec 2006), while fertilization conformed to the soil analyses.

\section{Site characteristic - soil properties}

The vineyard soil was characterized as a silty clay loam (18\% sand, $43 \%$ silt, $39 \%$ clay) with a $\mathrm{pH}$ of about 5.6 and total organic matter of $1.68 \%$. The available soil macroelement content, measured after $0.03 \mathrm{M} \mathrm{CH}_{3} \mathrm{COOH}$ extraction (Nowosielski 1988), was in the medium to optimum level for phosphorus, as well as for magnesium. The measured available soil potassium and calcium content was below the optimum limits. Average amounts of available soil microelements (extracted with $1 \mathrm{M} \mathrm{HCl}$ ) were in the optimum range for manganese, copper and zinc.

\section{Climatic conditions}

The meteorological data are presented in climate diagrams (Figs 1 A-C). The site of the experimental vineyard had a long-term average annual precipitation of $576 \mathrm{~mm}$ with an average minimum temperature of $-2.9^{\circ} \mathrm{C}$ (in January) and maximum

Table 1. Description of cultivars used in the experiment

\begin{tabular}{|c|c|c|c|c|}
\hline No. & Cultivar & Pedigree & $\begin{array}{l}\text { Grape } \\
\text { colour }\end{array}$ & $\begin{array}{l}\text { Country of } \\
\text { origin }\end{array}$ \\
\hline 1 & Aurora & 'Seibel' $788 \times$ ×Seibel' 29 & White & France \\
\hline 2 & Bianca & 'Seyve Villard' 12-375 × 'Bouvier' & White & Hungary \\
\hline 3 & Hibernal & 'Seibel' 7053 x 'Riesling' 239 & White & Germany \\
\hline 4 & Jutrzenka & 'Seyve Villard' 12-375 × 'Pinot Blanc' & White & Poland \\
\hline 5 & Muskat Odeski & 'Muskat Sinij Ranij' × 'Seyve Villard’ 20-366 & White & Ukraine \\
\hline 6 & $\begin{array}{l}\text { Seyval Blanc syn. 'Seyve } \\
\text { Villard' } 5-276\end{array}$ & 'Seibel' $4995 \times$ ×'Seibel' 4986 & White & France \\
\hline 7 & Sibera & $\begin{array}{l}\text { 'Saperavi Siewiernyj' × ('Foster White Seedling' } \\
\text { × 'Prachtraube' }\end{array}$ & White & Germany \\
\hline 8 & Frontenac & V. riparia $89 \times$ 'Landot' 4511 & Red & USA \\
\hline 9 & Leon Millot & 101-14 Mgt. × 'Goldriesling' & Red & France \\
\hline 10 & $\begin{array}{l}\text { Marechal Foch syn. 'Kuhlmann' } \\
188-2\end{array}$ & MgT101-14 × 'Goldriesling' & Red & France \\
\hline 11 & Regent & ('Sylvaner' × 'Müller Thurgau') $\times$ 'Chambourcin' & Red & Germany \\
\hline 12 & Rondo syn. Gm 6494-5 & 'Saperawi Siewiernyj' $\times$ 'Saint Laurent' & Red & Germany \\
\hline 13 & Swenson Red & 'Minnesota' \#78 × 'Seibel' 11803 & Red & USA \\
\hline
\end{tabular}



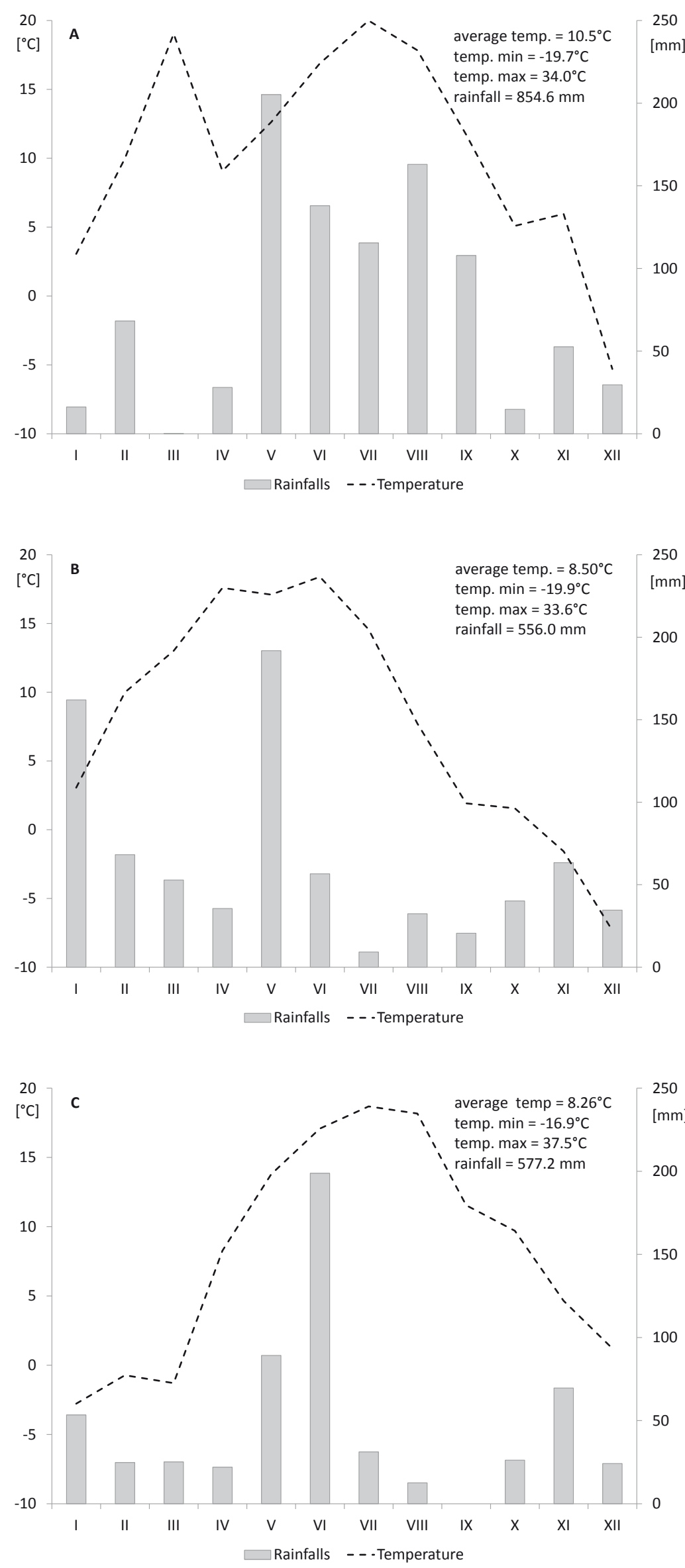

Figure 1. Climate diagrams for 2010 (A), 2011 (B) and 2013 (C), according to Walther and Lieth (1960) 
temperature of $17.8^{\circ} \mathrm{C}$ (in July). In 2010, the temperatures for the vegetation period were near the average, while the rainfalls recorded for 2010 were heavy, especially in May and September. This vintage was warmer, as the average temperature recorded from April to September was $14.7^{\circ} \mathrm{C}$ compared to $12.9^{\circ} \mathrm{C}$ recorded in 2011. Higher precipitation $(757 \mathrm{~mm}$ and $346 \mathrm{~mm} 2010$ and 2011, respectively) was also noted. The year 2011 was dry, except for May, and colder compared to multi-annual temperatures. 2013 had an annual precipitation of $577 \mathrm{~mm}$ and maximum rainfall in June/July, which was beneficial for flowering and fruit setting. Favourable climatic conditions (low precipitation and relatively high temperatures) were recorded before the harvest. The calculated sums of active temperatures (SAT) were: $2755^{\circ} \mathrm{C}, 2481^{\circ} \mathrm{C}$ and $2764^{\circ} \mathrm{C}$ for the 2010,2011 and 2013 vintage, respectively.

\section{Plant parameter measurements}

The tree trunk diameter of each vine was measured every year at a height of $30 \mathrm{~cm}$ above the soil, with the result being calculated per trunk cross-section area $\left(\mathrm{TCSA}, \mathrm{cm}^{2}\right)$. The total yield per vine was weighted and the productivity index was calculated (the total yield divided by the TCSA, expressed in $\mathrm{kg} \mathrm{cm}{ }^{-2}$ ).

\section{Fruit analyses - sample preparation}

Grapes were harvested at their optimum maturity. Three samples, each consisting of 20 randomly chosen bunches of grapes, were taken for each cultivar. Berries showing average growth and maturation were sampled for each treatment. The grapes were washed in distilled water and the pedicels were removed after drying at room temperature. Juices were obtained using a $\mathrm{PH} 2$ (Taco, Poland) laboratory vertical hydraulic press. The soluble solids concentration (SSC) of juices was determined using a digital refractometer (model PR-100, Atago) at $22^{\circ} \mathrm{C}$. Titratable acidity (TA) was ascertained titrating the juice with $0.1 \mathrm{M} \mathrm{NaOH}$ to pH 8.1 and expressed as tartaric acid equivalents (g $\left.100 \mathrm{~mL}^{-1}\right)$. The sugar:acid ratio was derived using ${ }^{\circ}$ Brix and acidity values.

Each sample was then centrifuged at $3000 \mathrm{rpm}$ for 15 minutes and diluted with deionized water $(\mathrm{v} / \mathrm{v}$ 1:60) for the purpose of the direct determination of organic acids.

For the purpose of measuring antioxidant activity and total phenolic content, grape juices were extracted using methanol in 1:5 proportion for $2 \mathrm{~h}$, and then centrifuged at $3000 \mathrm{rpm}$ for 15 minutes.

\section{Instrumentation}

A FRAP (Ferric Reducing Antioxidant Power) assay was conducted as described by Paśko et al. (2009). FRAP analysis was carried on at $37^{\circ} \mathrm{C}$ and $\mathrm{pH}$ 3.6. The reduction of ferric tripyridyltriazine (Fe(III)TPTZ) complex to ferrous tripyridyltriazine (Fe(II)-TPTZ) (which has an intensive blue colour) was monitored by measuring a change in absorption at $593 \mathrm{~nm}$ by a Synergy 2 Multi-Mode Microplate reader spectrophotometer from Bio Tek Instruments. The absorbance was measured after 30 minutes and was proportional to the antioxidant capacity of the antioxidants in the samples. The standard curve was linear between 0.25 and 1.50 mmol dm${ }^{-3} \mathrm{FeSO}_{4} \times \mathrm{H}_{2} \mathrm{O}$. The final results were given as $\mu \mathrm{mol} \mathrm{Fe}{ }^{2+} \mathrm{kg}^{-1}$.

Total phenolic compounds (TPC) were determined using the Follin-Ciocalteu reagent. The analytical procedure was performed as described earlier (Paśko et al. 2009) with some modifications. Total phenolic assay was carried out by mixing 540 $\mu \mathrm{L}$ of deionised water, $60 \mu \mathrm{L}$ of methanol extract, $60 \mu \mathrm{L} 7 \% \mathrm{Na}_{2} \mathrm{CO}_{3}$, and $30 \mu \mathrm{L}$ Follin-Ciocalteu solution. The absorbance was measured at 725 nm using a UV/VIS laboratory spectrophotometer (Synergy 2, Bio Tek Instruments). Total phenol content was determined using the standard gallic acid calibration curve (0.05-0.30 $\mathrm{g} \mathrm{L}^{-1}$ gallic acid). Final results were expressed as $\mathrm{g} \mathrm{L}^{-1}$ gallic acid equivalents (GAE).

Tartaric, malic and citric acid was determined using the Electrophoretic Analyser EA 202M (Villa Labeco, Spisska Nova Ves, Slovakia) with conductivity detection. The leading electrolyte

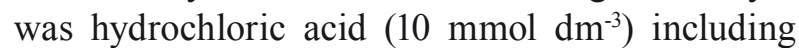
$0.2 \%$ methylhydroxyethylcellulose (M-HEC) adjusted with $\beta$-alanine to $\mathrm{pH} 3.5$. The terminating electrolyte contained $5 \mathrm{mmol} \mathrm{dm}^{-3}$ caproic acid and $5 \mathrm{mmol} \mathrm{dm}^{-3}$ histidine. The system was equipped with a sample valve of $30 \mu \mathrm{m}$ fixed volume and two capillaries: the pre-separation capillary ( 90 $\mathrm{mm} \times 0.9 \mathrm{~mm}$ internal diameter) and analytical capillary $(160 \mathrm{~mm} \times 0.3 \mathrm{~mm}$ I.D.). Samples were diluted with distilled water in order to obtain an acid concentration range between 10 and $80 \mathrm{mg} \mathrm{L}^{-1}$. The obtained values are expressed as $\mathrm{g} \mathrm{L}^{-1}$, except for ascorbic acid $-\mathrm{mg} \mathrm{L}^{-1}$.

\section{Statistical analysis}

Data were analysed using the Statistica 9.0 software (StatSoft Inc.). All results were subjected to one- 
way analysis of variance (ANOVA). The least significant differences (LSD) were ascertained with a multiple Duncan multiple range test (Duncan and Duncan 1955).

\section{RESULTS AND DISCUSSION}

In viticulture research, the trunk cross-sectional area of vines is assumed as a good descriptor characterizing vineyards. TCSA is well related to average factors limiting vine photosynthetic activity, while trunk average growth is also well correlated with average yield and sugar production per vine (Santesteban et al. 2010). In the presented study, the lowest TCSA was recorded for 'Aurora' and 'Seyval Blanc' in cultivars bearing white grapes, while the strongest vigour was proved for 'Hibernal' vines $\left(4.75,5.21\right.$ and $9.32 \mathrm{~cm}^{2}$, respectively, with measurements made in autumn 2013, Tab. 2). Among the investigated red cultivars, a tendency for weak growth was noted for 'Regent' $\left(5.66 \mathrm{~cm}^{2}\right)$, whereas 'Rondo' and 'Frontenac' revealed the opposite (7.43 and $7.42 \mathrm{~cm}^{2}$, respectively).

Mean yield per one vine is presented in Table 3. When averaged for three years of data, the

Table 2. Trunk cross section area $\left(\mathrm{TCSA}, \mathrm{cm}^{2}\right)$ and its increment $\left(\Delta \mathrm{TCSA}, \mathrm{cm}^{2}\right)$ as influenced by different grapevine cultivars

\begin{tabular}{llccc}
\hline Grape colour & Cultivar & Spring 2010 & Autumn 2013 & $\Delta$ TCSA \\
\hline White & Aurora & $0.53 \mathrm{a}^{*}$ & $4.75 \mathrm{a}$ & $4.21 \mathrm{a}$ \\
& Bianca & $0.63 \mathrm{a}$ & $8.12 \mathrm{e}-\mathrm{g}$ & $7.49 \mathrm{hi}$ \\
& Hibernal & $0.86 \mathrm{~cd}$ & $9.32 \mathrm{~g}$ & $8.46 \mathrm{i}$ \\
& Jutrzenka & $1.33 \mathrm{e}$ & $8.48 \mathrm{fg}$ & $7.15 \mathrm{f}-\mathrm{h}$ \\
& Muskat O. & $1.64 \mathrm{f}$ & $8.71 \mathrm{fg}$ & $7.06 \mathrm{f}-\mathrm{h}$ \\
& Seyval Blanc & $0.66 \mathrm{a}-\mathrm{c}$ & $5.21 \mathrm{ab}$ & $7.55 \mathrm{ab}$ \\
& Sibera & $0.94 \mathrm{~d}$ & $8.15 \mathrm{e}-\mathrm{g}$ & $6.21 \mathrm{gh}$ \\
\hline Red & Frontenac & $0.65 \mathrm{a}-\mathrm{c}$ & $7.42 \mathrm{~d}-\mathrm{f}$ & $5.45 \mathrm{~b}-\mathrm{e}$ \\
& Leon Millot & $0.65 \mathrm{a}-\mathrm{c}$ & $6.10 \mathrm{a}-\mathrm{d}$ & $4.89 \mathrm{a}-\mathrm{d}$ \\
& Marechal Foch & $1.29 \mathrm{e}$ & $6.18 \mathrm{~b}-\mathrm{d}$ & $4.72 \mathrm{a}-\mathrm{c}$ \\
& Regent & $0.86 \mathrm{~cd}$ & $5.66 \mathrm{a}-\mathrm{c}$ & $6.20 \mathrm{e}-\mathrm{h}$ \\
& Rondo & $1.22 \mathrm{e}$ & $7.43 \mathrm{~d}-\mathrm{f}$ & $5.13 \mathrm{~d}-\mathrm{g}$ \\
\hline
\end{tabular}

*Means designated with the same letter do not differ significantly at $\mathrm{p}=0.05$

Table 3. The average yield of 13 grapevine cultivars $\left(\mathrm{kg}\right.$ vine $\left.\mathrm{e}^{-1}\right)$

\begin{tabular}{llllll}
\hline \multirow{2}{*}{ Grape colour } & Cultivar & \multicolumn{3}{c}{ Year } & Mean \\
\cline { 3 - 4 } White & Aurora & 2010 & 2011 & 2013 & $2.24 \mathrm{~b}$ \\
& Bianca & $1.30 \mathrm{bc} *$ & $1.48 \mathrm{ab}$ & $3.41 \mathrm{~cd}$ & $1.72 \mathrm{a}$ \\
& Hibernal & $0.85 \mathrm{ab}$ & $0.91 \mathrm{a}$ & $2.75 \mathrm{a}-\mathrm{d}$ & $2.35 \mathrm{bc}$ \\
& Jutrzenka & $1.03 \mathrm{ab}$ & $2.98 \mathrm{f}$ & $2.01 \mathrm{a}$ & $1.56 \mathrm{a}$ \\
& Muskat O. & $0.75 \mathrm{a}$ & $1.53 \mathrm{ab}$ & $3.54 \mathrm{~d}$ & $2.33 \mathrm{~b}$ \\
& Seyval Blanc & $1.55 \mathrm{c}$ & $1.89 \mathrm{~b}-\mathrm{d}$ & $3.56 \mathrm{~d}$ & $2.80 \mathrm{c}$ \\
& Sibera & $1.31 \mathrm{bc}$ & $2.88 \mathrm{f}$ & $2.88 \mathrm{a}-\mathrm{d}$ & $2.35 \mathrm{~b}$ \\
\hline \multirow{2}{*}{ Red } & Frontenac & $1.09 \mathrm{a}-\mathrm{c}$ & $2.67 \mathrm{ef}$ & $3.51 \mathrm{~d}$ & $2.64 \mathrm{bc}$ \\
& Leon Millot & $0.81 \mathrm{bc}$ & $2.45 \mathrm{~d}-\mathrm{f}$ & $2.60 \mathrm{a}-\mathrm{c}$ & $1.82 \mathrm{a}$ \\
& Marechal Foch & $1.07 \mathrm{a}-\mathrm{c}$ & $1.52 \mathrm{ab}$ & $2.12 \mathrm{a}$ & $1.75 \mathrm{a}$ \\
& Regent & $1.23 \mathrm{a}-\mathrm{c}$ & $1.39 \mathrm{ab}$ & $3.09 \mathrm{~b}-\mathrm{d}$ & $1.78 \mathrm{a}$ \\
& Rondo & $0.91 \mathrm{ab}$ & $1.51 \mathrm{ab}$ & $2.35 \mathrm{ab}$ & $3.80 \mathrm{a}$ \\
& Swenson Red & $0.90 \mathrm{ab}$ & $2.22 \mathrm{c}-\mathrm{e}$ & $3.60 \mathrm{~d}$ & $2.24 \mathrm{~b}$ \\
\hline
\end{tabular}

\footnotetext{
*Explanation: see Table 2
} 
Table 4. Soluble solids content of grape juices ( ${ }^{\circ}$ Brix)

\begin{tabular}{|c|c|c|c|c|c|}
\hline \multirow{2}{*}{ Grape colour } & \multirow{2}{*}{ Cultivar } & \multicolumn{3}{|c|}{ Year } & \multirow{2}{*}{ Mean } \\
\hline & & 2010 & 2011 & 2013 & \\
\hline \multirow[t]{7}{*}{ White } & Aurora & $16.6 \mathrm{~d}^{*}$ & $16.5 \mathrm{a}$ & $16.5 \mathrm{a}$ & $16.5 \mathrm{abc}$ \\
\hline & Bianca & $16.6 \mathrm{~d}$ & $20.0 \mathrm{i}$ & $18.1 \mathrm{ab}$ & $18.4 \mathrm{~b}-\mathrm{e}$ \\
\hline & Hibernal & $15.9 \mathrm{~d}$ & $21.8 \mathrm{~m}$ & $21.2 \mathrm{~b}$ & $20.3 \mathrm{de}$ \\
\hline & Jutrzenka & $12.2 \mathrm{a}$ & $20.8 \mathrm{k}$ & $14.8 \mathrm{a}$ & $18.1 \mathrm{~b}-\mathrm{e}$ \\
\hline & Muskat O. & $15.2 \mathrm{~d}$ & $18.1 \mathrm{~b}$ & $15.3 \mathrm{a}$ & $16.7 \mathrm{a}-\mathrm{d}$ \\
\hline & Seyval Blanc & $15.0 \mathrm{bcd}$ & 21.01 & $18.3 \mathrm{ab}$ & $18.5 \mathrm{~b}-\mathrm{e}$ \\
\hline & Sibera & $12.9 \mathrm{ab}$ & $20.2 \mathrm{j}$ & $15.9 \mathrm{a}$ & $16.7 \mathrm{a}-\mathrm{d}$ \\
\hline \multirow[t]{6}{*}{ Red } & Frontenac & $17.1 \mathrm{~d}$ & $22.7 \mathrm{n}$ & $22.6 \mathrm{~b}$ & $20.8 \mathrm{e}$ \\
\hline & Leon Millot & $15.8 \mathrm{~d}$ & $18.9 \mathrm{f}$ & $18.5 \mathrm{ab}$ & $17.8 \mathrm{~b}-\mathrm{e}$ \\
\hline & Marechal Foch & $15.0 \mathrm{bcd}$ & $18.3 \mathrm{c}$ & $16.3 \mathrm{a}$ & $16.5 \mathrm{a}-\mathrm{d}$ \\
\hline & Regent & $14.9 \mathrm{bcd}$ & $19.6 \mathrm{~h}$ & $18.5 \mathrm{ab}$ & $18.3 \mathrm{~b}-\mathrm{e}$ \\
\hline & Rondo & $15.2 \mathrm{~cd}$ & $18.7 \mathrm{e}$ & $18.2 \mathrm{ab}$ & $17.8 \mathrm{~b}-\mathrm{e}$ \\
\hline & Swenson Red & $13.3 \mathrm{abc}$ & $18.5 \mathrm{~d}$ & $14.4 \mathrm{a}$ & $15.7 \mathrm{abc}$ \\
\hline
\end{tabular}

*Explanation: see Table 2

crops varied significantly among the cultivars. On average, the least productive cultivars produced 5.0 $\mathrm{t} \mathrm{ha}^{-1}$, while the most efficient produced $8.9 \mathrm{tha}^{-1}$.

The highest yields of white grapes were harvested from 'Seyval Blanc' (2.80 kg per vine) and 'Hibernal' (2.35). 'Frontenac' outperformed other red varieties (2.64 $\mathrm{kg}$ per vine). The cultivars with moderate yields were 'Aurora', 'Muscat Odeskij' and 'Sibera' (white) as well as 'Swenson Red' (red grapes). The rest of the investigated clones were less productive. Some authors have suggested that yield is negatively correlated with vine vigour (Wolf and Pool 1988, Parejo et al. 1995). The present study results confirmed these findings. The most productive, assuming the yield efficiency index, were 'Seyval Blanc' and 'Aurora' (1.84 and $1.60 \mathrm{~kg}$ $\mathrm{cm}^{-2}$, respectively; data not presented). Among red varieties the most efficient were 'Swenson Red', 'Frontenac' and 'Regent' (1.31, 1.16 and $1.13 \mathrm{~kg}$ $\mathrm{cm}^{-2}$, respectively). The yield efficiency index for the rest of the investigated clones varied from 0.65 to $1.00 \mathrm{~kg} \mathrm{~cm}^{-2}$.

There were some noteworthy differences in yielding between vintages. The highest crops were obtained in 2013. This increase was caused by a lack of fruiting in 2012 due to heavy flower frost damages. The high productivity of 'Seyval Blanc' as well as the obtained yields of the investigated clones confirmed previous reports by Lisek (2005, 2010). In addition, the crop results for 'Regent' was similar to these reported by Ochmian et al. (2013) in Pomerania, Poland. The obtained yields were lower than reported by Pacifico et al. (2013) (4.1 to
$11.7 \mathrm{~kg}$ per vine) in northeastern Italy. The present study also did not confirm the high productivity of 'Regent'. However, the differences were caused not only by different climatic/soil conditions but also by different training systems.

\section{Fruit composition}

The quality of grapes depends on sugar concentration, acidity, colour, texture and the aroma and flavour characteristics of the variety. Although sugar concentration is a common quality measure for grapes, there is not always a good relationship between it and the palatability of grapes. The ratio of berry juice ${ }^{\circ}$ Brix to acidity can give a better measurement of the palatability of grapes or musts than either the sugar content or acidity alone (Winkler et al. 1974). In cool climates, the acids will be higher relative to the sugar, so more of the latter will be required to balance the taste.

Soluble solids content varied from $15.7^{\circ}$ Brix (mean for 'Swenson Red') to $20.8^{\circ}$ Brix ('Frontenac', Tab. 4). Some authors (Lisek 2010, Pacifico et al. 2013) have pointed out large differences in soluble solids content among the hybrids, which reflect differences in their genotypes and the annual climate conditions. This variation was true in the presented study; however, in most cases the obtained SSC level was lower. The main reason was the low sugar content of grapes in 2010 as a consequence of high precipitation before the vintage. During ripening, excessive humidity is unfavourable to maturation (Tonietto 1999), due to the promotion of sugar dilution (Reynolds and Naylor 1994). 
Table 5. Acidity as $\mathrm{pH}$ of different grape juices

\begin{tabular}{llllll}
\hline \multirow{2}{*}{ Grape colour } & Cultivar & & Year & & \multirow{2}{*}{ Mean } \\
\cline { 3 - 4 } White & Aurora & 2010 & 2011 & 2013 & $3.59 \mathrm{def}$ \\
& Bianca & $3.33 \mathrm{bc}$ & $3.69 \mathrm{hi}$ & $3.67 \mathrm{c}$ & $3.72 \mathrm{fi}$ \\
& Hibernal & $3.61 \mathrm{fg}$ & $3.71 \mathrm{hi}$ & $3.85 \mathrm{e}$ & $3.57 \mathrm{c}-\mathrm{f}$ \\
& Jutrzenka & $3.34 \mathrm{bc}$ & $3.55 \mathrm{e}$ & $3.76 \mathrm{~d}$ & $3.46 \mathrm{bcd}$ \\
& Muskat O. & $3.26 \mathrm{a}$ & $3.48 \mathrm{~cd}$ & $3.54 \mathrm{~b}$ & $3.70 \mathrm{fi}$ \\
& Seyval Blanc & $3.53 \mathrm{e}$ & $3.71 \mathrm{i}$ & $3.85 \mathrm{e}$ & $3.57 \mathrm{c}-\mathrm{f}$ \\
& Sibera & $3.51 \mathrm{ef}$ & $3.52 \mathrm{de}$ & $3.66 \mathrm{c}$ & $3.57 \mathrm{c}-\mathrm{f}$ \\
\hline \multirow{2}{*}{ Red } & Frontenac & $3.42 \mathrm{~d}$ & $3.64 \mathrm{fg}$ & $3.63 \mathrm{c}$ & $3.42 \mathrm{abc}$ \\
& Leon Millot & $3.87 \mathrm{~h}$ & $3.45 \mathrm{c}$ & $3.44 \mathrm{a}$ & $3.81 \mathrm{i}$ \\
& Marechal Foch & $3.29 \mathrm{ab}$ & $3.67 \mathrm{ghi}$ & $3.94 \mathrm{e}$ & $3.45 \mathrm{bcd}$ \\
& Regent & $3.67 \mathrm{~g}$ & $3.67 \mathrm{gh}$ & $3.73 \mathrm{~d}$ & $3.68 \mathrm{fi}$ \\
& Rondo & $3.33 \mathrm{bc}$ & $3.53 \mathrm{e}$ & $3.45 \mathrm{a}$ & $3.46 \mathrm{bcd}$ \\
& Swenson Red & $3.51 \mathrm{e}$ & $3.60 \mathrm{f}$ & $3.82 \mathrm{~d}$ & $3.64 \mathrm{ef}$ \\
\hline
\end{tabular}

*Explanation: see Table 2

A high variability was observed among the investigated cultivars, which reflects differences in their genotypes/parentage and the annual climate conditions, showing the strong effect of the cultivar on the $\mathrm{pH}$ and titratable acid concentration (Pavloušek and Kumšta 2011, Pacifico et al. 2013). The $\mathrm{pH}$ along with acidity is not only responsible for the pigmentation of the grapes/musts, but is also an important factor in fermentation. At a low $\mathrm{pH}$, other conditions being equal, the fermentation will be cleaner, while wine will be less prone to spoiling. Keller (2010) pointed out that the $\mathrm{pH}$ values of musts should not exceed 3.6 in order to avoid a decrease of wine quality. Except for 'Bianca', 'Muscat Odesskij' and 'Leon Millot', all of the studied cultivars conformed this criterion (Tab. 5).

The highest titratable acidity was measured for 'Marechal Foch' (Tab. 6), and among white grapes, for 'Jutrzenka'. All of the other white grapes had low TA along with the following red varieties: 'Regent' (0.64 g $\left.100 \mathrm{~mL}^{-1}\right)$, 'Leon Millot' and 'Swenson Red'. The presented values are higher than those obtained by Almanza et al. 2010 in

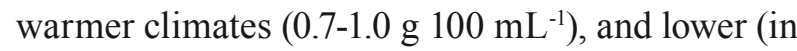
the case of 'Regent') than for conditions in northern

Table 6. Titratable acidity of grape juices $\left(\mathrm{g} 100 \mathrm{~mL}^{-1}\right)$ as affected by different grapevine cultivars

\begin{tabular}{llllll}
\hline \multirow{2}{*}{ Grape colour } & Cultivar & & Year & \multirow{2}{*}{ Mean } \\
\cline { 3 - 5 } White & Aurora & 2010 & 2011 & 2013 & $0.82 \mathrm{ab}$ \\
& Bianca & $1.19 \mathrm{~d}^{*}$ & $0.67 \mathrm{a}$ & $0.68 \mathrm{~d}$ & $0.81 \mathrm{ab}$ \\
& Hibernal & $0.99 \mathrm{~b}-\mathrm{d}$ & $0.80 \mathrm{~cd}$ & $0.65 \mathrm{c}$ & $0.83 \mathrm{ab}$ \\
& Jutrzenka & $1.20 \mathrm{~d}$ & $0.76 \mathrm{bc}$ & $0.68 \mathrm{~d}$ & $1.06 \mathrm{c}$ \\
& Muskat O. & $0.75 \mathrm{ab}$ & $1.13 \mathrm{~g}$ & $1.07 \mathrm{~g}$ & $0.65 \mathrm{a}$ \\
& Seyval Blanc & $0.71 \mathrm{a}$ & $0.73 \mathrm{~b}$ & $0.48 \mathrm{a}$ & $0.81 \mathrm{ab}$ \\
& Sibera & $0.83 \mathrm{ab}$ & $0.75 \mathrm{bc}$ & $0.86 \mathrm{f}$ & $0.74 \mathrm{ab}$ \\
\hline Red & Frontenac & $0.85 \mathrm{ab}$ & $0.78 \mathrm{~b}-\mathrm{d}$ & $0.57 \mathrm{~b}$ & $1.55 \mathrm{e}$ \\
& Leon Millot & $1.64 \mathrm{e}$ & $1.51 \mathrm{i}$ & $1.50 \mathrm{~h}$ & $0.84 \mathrm{ab}$ \\
& Marechal Foch & $0.88 \mathrm{a}-\mathrm{c}$ & $0.88 \mathrm{e}$ & $0.75 \mathrm{e}$ & $1.24 \mathrm{~d}$ \\
& Regent & $1.24 \mathrm{~d}$ & $1.36 \mathrm{~h}$ & $0.13 \mathrm{~h}$ & $0.64 \mathrm{a}$ \\
& Rondo & $0.63 \mathrm{a}$ & $0.68 \mathrm{a}$ & $0.57 \mathrm{~b}$ & $0.91 \mathrm{bc}$ \\
& Swenson Red & $0.74 \mathrm{ab}$ & $0.95 \mathrm{f}$ & $0.73 \mathrm{e}$ & $0.77 \mathrm{ab}$ \\
\hline
\end{tabular}

\footnotetext{
*Explanation: see Table 2
} 
Table 7. Sugar:acid (SSC:TA) ratio of grape juices as affected by different grapevine cultivars

\begin{tabular}{|c|c|c|c|c|c|}
\hline \multirow{2}{*}{ Grape colour } & \multirow{2}{*}{ Cultivar } & \multicolumn{3}{|c|}{ Year } & \multirow{2}{*}{ Mean } \\
\hline & & 2010 & 2011 & 2013 & \\
\hline \multirow[t]{7}{*}{ White } & Aurora & $14.0 \mathrm{a}-\mathrm{d}^{*}$ & $24.5 \mathrm{~g}$ & $24.1 \mathrm{de}$ & $21.5 \mathrm{c}-\mathrm{e}$ \\
\hline & Bianca & $16.7 \mathrm{c}-\mathrm{e}$ & $25.1 \mathrm{gh}$ & $28.1 \mathrm{e}-\mathrm{g}$ & $23.5 \mathrm{~d}-\mathrm{f}$ \\
\hline & Hibernal & $13.6 \mathrm{a}-\mathrm{c}$ & $28.9 \mathrm{i}$ & $31.1 \mathrm{fg}$ & $26.2 \mathrm{ef}$ \\
\hline & Jutrzenka & $16.3 \mathrm{c}-\mathrm{e}$ & $18.4 \mathrm{c}$ & $13.8 \mathrm{~b}$ & $17.0 \mathrm{bc}$ \\
\hline & Muskat O. & $22.7 \mathrm{f}$ & $24.8 \mathrm{~g}$ & $31.7 \mathrm{~g}$ & $26.2 \mathrm{ef}$ \\
\hline & Seyval Blanc & $18.1 \mathrm{de}$ & $28.1 \mathrm{i}$ & $21.7 \mathrm{~cd}$ & $23.2 \mathrm{~d}-\mathrm{f}$ \\
\hline & Sibera & $15.2 \mathrm{~b}-\mathrm{e}$ & $26.1 \mathrm{~h}$ & $27.6 \mathrm{ef}$ & $23.3 \mathrm{~d}-\mathrm{f}$ \\
\hline \multirow[t]{6}{*}{ Red } & Frontenac & $10.4 \mathrm{a}$ & $15.0 \mathrm{~b}$ & $15.0 \mathrm{~b}$ & $13.5 \mathrm{ab}$ \\
\hline & Leon Millot & $18.8 \mathrm{e}$ & $21.4 \mathrm{e}$ & $24.7 \mathrm{de}$ & $21.6 \mathrm{c}-\mathrm{e}$ \\
\hline & Marechal Foch & $12.1 \mathrm{ab}$ & $13.3 \mathrm{a}$ & $14.4 \mathrm{~b}$ & $13.3 \mathrm{ab}$ \\
\hline & Regent & $23.7 \mathrm{f}$ & $29.0 \mathrm{i}$ & $32.0 \mathrm{~g}$ & $28.5 \mathrm{f}$ \\
\hline & Rondo & $13.4 \mathrm{a}-\mathrm{c}$ & $19.8 \mathrm{~d}$ & $25.1 \mathrm{de}$ & $12.1 \mathrm{~cd}$ \\
\hline & Swenson Red & $18.00 \mathrm{de}$ & $22.6 \mathrm{f}$ & $19.9 \mathrm{c}$ & $20.4 \mathrm{~cd}$ \\
\hline
\end{tabular}

*Explanation: see Table 2

Poland (Ochmian et al. 2013). The measured TA is typically higher for cool climates, and the acidity of musts is negatively correlated with temperature and irradiation (Alleweldt et al. 1984).

The technical index SSC:TA ratio was significantly differentiated between the investigated cultivars (Tab. 7). The highest values were noted for 'Regent' (28.48) and all of the white cultivars (ranging from 23.2 to 26.2) except for 'Aurora' and 'Jutrzenka' (21.5 and 17.0, respectively). However, the most balanced table wines tend to have a ratio between 30 and 35 (Cox 1999). This simply indicates too low of a sugar content due to high acidity, which is typical for cool climate grapes.

The principal acids of the grape are d-tartaric and 1-malic, constituting 90 per cent or more of the total acidity (Winkler et al. 1974). Grapevines are one of a few plants in which tartaric acid is synthetized in large amounts (Stafford 1959). Citric acid is the third most abundant acid in grapes, but mature fruits contain only 0.02 to $0.03 \%$ of this acid. Temperature is the most important environmental factor affecting the total acidity and the amount of malate and tartrate in grapes. The per cent malate and percentage of the titratable acidity due to malate is greater under cool temperatures than under warm temperatures. Kliewer (1971) showed that the amount of malic and tartaric acid in grapes is closely negatively correlated with the temperature during the ripening but relatively independent of light density.

In California, the titratable acidity of the juice of mature grapes varies from 0.30 to $1.20 \%$ (calculated as tartaric acid) depending on variety, season and climatic region. The proportion of the titratable acidity that is due to tartaric acid and acid tartrate increases with fruit maturity (Amerine 1951). Tartaric acid and acid tartrate are not as rapidly lost at higher temperatures as are malic acid and acid malate (Kliewer 1971).

As far as tartaric acid is concerned, 'Marechal Foch' grapes contained the highest amount of this compound (4.51 $\mathrm{g} \mathrm{L}^{-1}$, Tab. 8). The lowest concentration was measured for 'Frontenac' (1.03 $\left.\mathrm{g} \mathrm{L}^{-1}\right)$ as well as 'Jutrzenka' $\left(1.76 \mathrm{~g} \mathrm{~L}^{-1}\right)$. However, the latter cultivar tended to accumulate one of the highest malic acid amounts $\left(6.95 \mathrm{~g} \mathrm{~L}^{-1}\right)$. A slightly lower level was measured for 'Hibernal', 'Marechal Foch' and 'Rondo' (6.08, 6.06 and $5.95 \mathrm{~g} \mathrm{~L}^{-1}$, respectively). The lowest accumulation was typical for 'Regent' $\left(2.30 \mathrm{~g} \mathrm{~L}^{-1}\right)$. In the must of 'Jutrzenka', the increased citric acid content was ascertained $\left(1.89 \mathrm{~g} \mathrm{~L}^{-1}\right)$.

Vast differences were noted in ascorbic acid content (Tab. 8). Low contents were typical for white grapes cultivars (from 11.5 to $55.2 \mathrm{mg} \mathrm{L}^{-1}$ ) and some red ones: 'Regent', 'Rondo' and 'Swenson Red'. Medium values were ascertained for 'Leon Millot' ( $\left.90.4 \mathrm{mg} \mathrm{L}^{-1}\right)$, while the highest were found in 'Frontenac' (139.4 $\left.\mathrm{mg} \mathrm{L}^{-1}\right)$ and 'Marechal Foch' (184.0 $\left.\mathrm{mg} \mathrm{L}^{-1}\right)$. These values are within the mean vitamin $C$ concentration presented by the USDA (2014) for different species of grapes: 4.0 to $10.8 \mathrm{mg}$ $100 \mathrm{~g}^{-1}$ (V. labrusca and $V$. vinifera, respectively).

Phenolic compounds are responsible for the bitterness, astringency and colour intensity of 
Table 8. Organic acid concentration in grapes as influenced by different cultivars. Data expressed in $\mathrm{g} \mathrm{L}^{-1}$ except for ascorbic acid, expressed as $\mathrm{mg} \mathrm{L}^{-1}$

\begin{tabular}{lllllc}
\hline Grape colour & Cultivar & Tartaric & Malic & Citric & Ascorbic \\
\hline White & Aurora & $2.12 \mathrm{~b}^{*, * *}$ & $4.93 \mathrm{~b}$ & $0.63 \mathrm{~b}$ & $55.2 \mathrm{a}$ \\
& Bianca & $2.52 \mathrm{~b}$ & $4.35 \mathrm{~b}$ & $0.43 \mathrm{ab}$ & $13.1 \mathrm{a}$ \\
& Hibernal & $3.16 \mathrm{c}$ & $6.08 \mathrm{~cd}$ & $0.30 \mathrm{a}$ & $23.8 \mathrm{a}$ \\
& Jutrzenka & $1.76 \mathrm{a}$ & $6.95 \mathrm{~d}$ & $1.89 \mathrm{e}$ & $23.7 \mathrm{a}$ \\
& Muskat O. & $2.75 \mathrm{bc}$ & $4.21 \mathrm{~b}$ & $0.31 \mathrm{a}$ & $26.9 \mathrm{a}$ \\
& Seyval Blanc & $2.61 \mathrm{bc}$ & $4.68 \mathrm{~b}$ & $0.38 \mathrm{a}$ & $33.5 \mathrm{a}$ \\
& Sibera & $2.60 \mathrm{bc}$ & $4.77 \mathrm{~b}$ & $0.24 \mathrm{a}$ & $11.5 \mathrm{a}$ \\
\hline \multirow{2}{*}{ Red } & $1.03 \mathrm{a}$ & $6.78 \mathrm{~d}$ & $1.62 \mathrm{~d}$ & $139.4 \mathrm{bc}$ \\
& Frontenac & $3.34 \mathrm{~cd}$ & $4.09 \mathrm{~b}$ & $0.46 \mathrm{ab}$ & $90.4 \mathrm{ab}$ \\
& Leon Millot & $4.51 \mathrm{e}$ & $6.06 \mathrm{~cd}$ & $0.51 \mathrm{~b}$ & $184.0 \mathrm{c}$ \\
& Marechal Foch & $2.51 \mathrm{~b}$ & $2.30 \mathrm{a}$ & $0.28 \mathrm{a}$ & $72.0 \mathrm{a}$ \\
& Regent & $3.79 \mathrm{~d}$ & $5.95 \mathrm{~cd}$ & $1.00 \mathrm{c}$ & $73.5 \mathrm{a}$ \\
& Rondo & $2.98 \mathrm{~b}$ & $4.92 \mathrm{bc}$ & $0.53 \mathrm{~b}$ & $33.7 \mathrm{a}$ \\
\hline
\end{tabular}

*Explanation: see Table 2, **means were pooled across years 2010-13

Table 9. The total polyphenol content (TCP, g GAE L-1) and total antioxidant activity of the investigated grape juices measured by a Ferric-Reducing Antioxidant Power (FRAP, $\mu \mathrm{mol} \mathrm{Fe} \mathrm{kg}^{-1}$ ) assay

\begin{tabular}{llll}
\hline $\begin{array}{l}\text { Grape } \\
\text { colour }\end{array}$ & Cultivar & TCP & FRAP \\
\hline White & Aurora & $0.098 \mathrm{~b}^{* * * *}$ & $2195 \mathrm{~b}$ \\
& Bianca & $0.079 \mathrm{ab}$ & $1543 \mathrm{a}$ \\
& Hibernal & $0.064 \mathrm{ab}$ & $1658 \mathrm{a}$ \\
& Jutrzenka & $0.039 \mathrm{a}$ & $1760 \mathrm{ab}$ \\
& Muskat O. & $0.104 \mathrm{~b}$ & $3140 \mathrm{c}$ \\
& Seyval Blanc & $0.069 \mathrm{ab}$ & $2511 \mathrm{bc}$ \\
& Sibera & $0.059 \mathrm{ab}$ & $1590 \mathrm{a}$ \\
\hline Red & Frontenac & $0.442 \mathrm{e}$ & $7652 \mathrm{e}$ \\
& Leon Millot & $0.420 \mathrm{e}$ & $8171 \mathrm{e}$ \\
& Marechal Foch & $0.412 \mathrm{e}$ & $11072 \mathrm{f}$ \\
& Regent & $0.295 \mathrm{~d}$ & $5528 \mathrm{~d}$ \\
& Rondo & $0.193 \mathrm{c}$ & $2789 \mathrm{bc}$ \\
& Swenson Red & $0.128 \mathrm{bc}$ & $1753 \mathrm{ab}$ \\
\hline
\end{tabular}

*,**Explanations: see Table 8

musts and wine, therefore they play an important role in wine's sensory quality. Polyphenols (e.g. anthocyanins) are not only responsible for the palatability but they are also strong antioxidants (Romero et al. 2008). Price et al. (1995) found that there is a strong relationship between the amount of flavonols in berries and the degree to which they were exposed to the sun. A study by Spayd et al. (2002) demonstrated that sunlight along with temperature affects anthocyanin production.
Some studies argue that cool night temperatures in the period preceding the harvest (maturation/ ripening), combined with high diurnal temperatures, stimulate the synthesis of anthocyanins and other phenolic compounds, being thus beneficial for high-quality wines (Kliewer and Torres 1972, Mori et al. 2005).

The highest total polyphenol content was measured for red cultivars, namely 'Frontenac', 'Leon Millot' and 'Marechal Foch' (0.442, 0.420 and $0.412 \mathrm{~g} \mathrm{GAE} \mathrm{L}^{-1}$, respectively; Tab. 9). 'Regent' and 'Rondo' contained moderate TPC content, while 'Swenson Red' had the lowest. White grapes contained low polyphenol levels. The measured content varied from $0.039 \mathrm{~g} \mathrm{GAE} \mathrm{L}^{-1}$ ('Jutrzenka') to $0.104 \mathrm{~g} \mathrm{GAE} \mathrm{L}^{-1}$ ('Muskat Odesskij').

The highest total antioxidant potential was measured for 'Marechal Foch' grapes (11072 $\mu \mathrm{mol} \mathrm{Fe} \mathrm{kg}^{-1}$, Tab. 9), followed by 'Leon Millot' and 'Frontenac' (8171 and $7652 \mu \mathrm{mol} \mathrm{Fe} \mathrm{kg}{ }^{-1}$, respectively). These values are much higher than those obtained for Greek cultivars by Anastasiadi et al. (2010).

\section{CONCLUSIONS}

1. The cultivars 'Seyval Blanc', 'Aurora' and 'Regent' showed moderate growth but resulted in high yields.

2. Although the quality of some vintages obtained in a cool climate was not fully satisfying (frost injuries, too low sugar content, high acidity) the content of investigated secondary metabolites such as ascorbic acid and polyphenols, and 
consequently the high antioxidant potential of grapes, was prominent.

\section{ACKNOWLEDGEMENTS}

The study was financed by the Polish National Science Centre (project N N310 163338).

\section{REFERENCES}

Alleweldt G., Düring H., Jung K.H., 1984. Zum Einfluss des Klimas auf Beerenentwicklung, ertrag und qualität bei Reben: Ergebnisse einer siebenjährigen Faktorenanalyse. Vitis 23: 127-142.

Almanza P.J., Quljano-Rico M.A., Fisher G., Chaves B., Balagueralopez H.E., 2010. Physicochemical characterization of 'Pinot Noir' grapevine (Vitis vinifera $\mathrm{L}$.) fruit during its growth and development under high altitude tropical conditions. Agr. Colomb. 28: 173-180.

Amerine M.A., 1951. The acids in California grapes and wines. II. Malic acid. Food Tech. 5: 13-16.

Anastasiadi M., Pratsinis H., Kletsas D., Skaltsounis A-L., Haroutounian S.A., 2010. Bioactive noncoloured polyphenols content of grapes, wines and vinification by-products: Evaluation of the antioxidant activities of their extracts. Food Res. Int. 43: 805-813.

Cox J., 1999. From Vines to Wines. Fourth Edition, Storey Publishing LLC, North Adams, USA.

Dobrowolska-Iwanek J., Gastol M., Wanat A., KrośniaK M., Jancik M., Zagrodzki P., 2014. The wine of cool-climate of South Poland. S. Afr. J. Enol. Vitic. 31(1): 1-9.

Duncan O.D., Duncan B., 1955. A methodological analysis of segregation indexes. Am. Sociol. Rev. 20(2): 210-217.

EUROSTAT, 2012. Available online at http://epp. eurostat.ec.europa.eu/portal/page/portal/statistics/ search database; cited on 16 August 162014.

FAO, 2012. Available online at http://faostat.fao.org/; cited on 16 August 2014.

Gustafsson J.G., MÅrtensson A., 2005. Potential for extending Scandinavian wine cultivation. Acta Agric. Scand. B 55: 82-97.

KelLer M., 2010. The science of grapevines. Anatomy and Physiology, Academic Press, Burlington.

KLIEWER W.M., 1971. Effect of day temperature and light density on concentration of malic and tartaric acids in Vitis vinifera L. grapes. J. Amer. Soc. Hort. Sci. 96: 372-377.

KLIEWER W.M., TorRes R.E., 1972. Effect of controlled day and night temperatures on grape coloration. Am. J. Enol. Vitic. 22:172-177.

Lisek J., 2005. Zdrowotność, plonowanie i rozmnażanie wybranych genotypów winorośli (Vitis sp. L.) w warunkach Polski. Zeszyty Nauk. Inst. Sadow. Kwiac., Monografie i rozprawy, $94 \mathrm{pp}$.
LISEK J., 2010. Yielding and healthiness of selected grape cultivars for processing in central Poland. J. Fruit Ornam. Plant. Res. 18(2): 265-272.

Mori K.., Sugaya S., Gemma H. 2005. Decreased anthocyanin biosynthesis in grape berries grown under elevated night temperature condition. Sci. Hortic. 105: 319-330.

Myślıwiec R., 2006. Winorośl i wino. PWRiL, Warszawa.

Nowosielski O., 1988. Zasady opracowywania zaleceń nawozowych w ogrodnictwie. PWRiL. Warszawa.

Ochmian I., Grajkowski J., Chępiński P., Strzelecki R., 2013. The impact of cutting and mulching grapevine Regent on yielding and fruit quality. Folia Pomer. Univ. Technol. Stetin, Agric., Aliment., Pisc., Zootech. 304(26): 87-96.

Pacifico D., Gaiotti F., Giusti M., Tomasi D., 2013. Performance of interspecific grapevine varieties in north-east Italy Agr. Sci. 4(2): 91-101.

Parejo J., Minguez S., Sella J., Espinas E., 1995. Sixteen years of monitoring the cultivar Xarello (Vitis vinifera L.) on several rootstocks. Acta Hort. 388: 123-128.

Paśko P., Bartoń H., Zagrodzki P., Groinstein S., FoŁta M., Zachwieja Z., 2009. Antocyanins, total polyphenols and antioxidant activity in amaranth and quinoa seeds and sprouts during their growth. Food Chem. 115: 994-998.

Pavloušek P., Kumšta M., 2011. Profiling of primary metabolits in grapes of interspecific grapevine varieties: Sugars and organic acids. Czech J. Food Sci. 29: 361-372.

Price S.F., Breen P.J., Valladao M., Watson B.T., 1995. Cluster sun exposure and quercetin in Pinot noir grapes and wine. Am. J. Enol. Vitic. 46(2): 187-194.

Reynolds A.G., NAYlor A.P., 1994. Pinot-Noir and riesling grapevines respond to water-stress duration and soil water-holding capacity. HortSci. 29: 15051510.

Romero I., Sanchez-Ballesta M.T., Escribano M.I., Merodio C., 2008. Individual anthocyanins and their contribution to total antioxidant capacity in response to low temperature and high $\mathrm{CO}_{2}$ in stored Cardinal table grapes. Postharvest Biol. Tec. 49: 1-9.

Santesteban L.G., Miranda C., Royo J.B., 2010. Vegetative growth, reproductive development and vineyard balance. In: Methodologies and Results in Grapevine Research. S. Delrot, H. Medrano, E. Or, L. Bavaresco, S. Grando (eds), Springer Science+Media B.V, Dodrecht, Netherlands.

Spayd S.E., Tarara J.M., Mee D.L., Ferguson J.C., 2002. Separation of sunlight and temperature effects on the composition of Vitis vinifera $\mathrm{cv}$. Merlot berries. Am. J. Enol. Vitic. 53(3): 171-182.

Stafford H., 1959. Distribution of tartaric acid in the leaves of certain angiosperms. Amer. J. Bot. 46: $347-352$. 
Tonietto J., Carbonneau A., 2004. A multicriteria climatic classification system for grape-growing regions worldwide. Agric. For. Meteorol. 124: 81-97.

USDA., 2014. USDA Nutrient Database for Standard Reference, Release 27. Available online at https:// www.ars.usda.gov/Services/docs.htm?docid=8964 ov/ba/bhncr/ndl; cited on 16 August 2014.

Walter H., Lieth H., 1960. Klimadiagramm - Weltatlas, VEB Gustav Fischer Verlag, Jena.
Winkler A.J., Cook J.A., Kliewer W.M., Lider L.A., 1974. General viticulture. University of California Press, Berkeley, California.

Wolf T.K., Pool R.M., 1988. Effects of rootstock and nitrogen fertilization on the growth and yield of Chardonnay grapevines in New York. Am. J. Enol. Vitic. 39: 29-33.

Received November 1, 2014; accepted February 4, 2015 